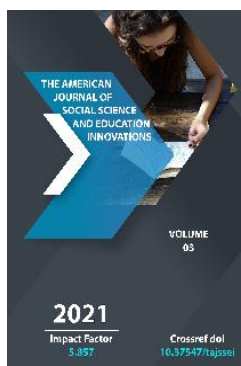

\title{
Performance And Art
}

\section{Khilola Tursunbaevna Botirova}

Associate Professor Of The Faculty Of Art History Of Andizhan State University, Andizhan Region, Republic Of Uzbekistan

\section{ABSTRACT}

This article provides detailed information about the performing arts, including scientific and theoretical information about the commonality of performance and art. The scholars' scientific approaches to music are described in detail.

\section{KEYWORDS}

Performance, creativity, skill, reading, brochures, culture, art, musical instruments.

\section{INTRODUCTION}

In summarizing this article for you, I found it necessary to share with you the steps to reach this process. In the process of implementation of the "Action Strategy for the five priority areas of development of the Republic of Uzbekistan in 2017-2021", approved by the Decree of the President of the Republic of
Uzbekistan dated February 7, 2017 PD-4947, a new stage in the development of music has begun. The radical reforms that are being carried out today are also yielding results in the ongoing Resolutions and projects. 
The meeting which was held in March 19, 2019 under the chairmanship of President of the Republic of Uzbekistan Shavkat Mirziyoyev focusing on strengthening attention to youth, wide involvement of the younger generation in culture, arts, physical culture and sports, the formation of skills in the proper use of information technology, promotion of reading among youth, women's employment set important tasks to raise the morale of young people, the meaningful organization of their leisure time. We can see that the results of this task and execution are bearing fruit in today's fields of education.

\section{METHODS}

The visit of our President began from Syrdarya region and in a short time great work was done. 300,000 copies of fiction were delivered to district and city libraries in the region. Music and art schools were equipped with musical instruments, sports facilities were equipped. Thanks to the efforts of the President, this process was continued in Namangan region, and the "Caravan of Enlightenment" was organized. 25,000 books, 80 types of sports equipment and musical instruments were delivered to young people. All the following efforts require that all conditions are opened for the youth of the future, and that this process be promoted with speed and justice, which is a sign of spiritual growth.

\section{RESULTS AND DISCUSSIONS}

That is why in the field of art we often come across the words performance and creativity, sometimes ignoring the importance of these words in human life. At the same time, realizing that the words performance and art are complementary, when we say the art of performance, we always think of our composers and thinkers. And we feel that the heritage of these creative intellectuals is a beacon of light from the past. So let's talk with you about the words of performance and art, what are the complementary phrases of performance and art, what does the word performance mean? The question naturally arises, we can carry this word from each of our activities. Not to be indifferent to this phrase, as every task assigned is its own execution, we are witnessing not only today, but historically, this phrase has been treated fairly. From our achievements and victories we can understand that all this is the product of fruitful work and hard work.

In this article, we will take a scientific approach to the achievements and problems of the performing arts. The art of performance did not enter our lives yesterday or today, on the contrary, there is information in our legends and myths that the giving of life to a person came under the performance of musical melodies on the flute. The subject of music is covered in more hadiths. Various scientific studies have shown that there are two main reasons for resistance to music. Each cause corresponds to a certain historical period and is associated with politicalideological as well as cultural development.

The first resistance to music dates back to the VII-VIII centuries. Although Islam had no opposition to Christianity, Judaism, or Zoroastrianism, it fought fiercely against its "internal enemies," paganism and polytheism. These "elements" were reflected in the Arabs (before the introduction of Islam) in materials such as sound, words, and images. The encyclopedic scholars of the Brotherhood of Purity (10th century) also testified to the reasons for the ban.\{1.271-272\} Alisher Navoi, in turn, gave this category of musicians a "decent definition" in his opinion $\{2\}\{2.29\}$.

The reason for bringing our opinion from afar is also to show skill and mastery in the 
performing arts. In this regard, one of the rules of the law is to recite the Holy Quran, the holy book of the Uzbek people.

The muezzins of the Azan (Sufis) tried to explain the issues of recitation in detail in medieval prose sources. We all know that reading the Qur'an has become an art because of the strict observance of the rules of recitation.

One noteworthy aspect of this was that the ability to memorize and the ability to read with reading were considered to be one of the most essential aspects and had proven themselves in practice. When it comes to recitation, it is appropriate to mention the name of Abdul Qadir Maroghi.

There is also information in medieval scientific sources about the use of certain maqom lads for reading the Qur'an. Maqom lads were also used to say the azan. For example, in one of the Arab mosques, the call to prayer is called every day using different maqom lads, such as Ushshak, Rost, Segoh, Chorgoh.

Just as religious and secular sciences are embodied in our lives, so these aspects alone are an indication of how complex the sciences are when we reflect the essence of our performing arts. In this sense, the first President of the Republic I.A. Karimov said: "We value and respect the religion of Islam, the sacred religion of our ancestors, and its role and influence in strengthening the faith and human qualities in the spiritual world of mankind" $\{3\}$. $\{3 \cdot 300\}$.

When it comes to the performing arts, we have no choice but to justify the paths traversed by our great ancestors. One of the greatest representatives of Oriental music, Farobi (pseudonym, full name Abu Nasr Muhammad ibn Uzlug Tarhan Farobi) is the greatest representative of medieval Eastern music culture. According to sources, he was a great composer and a master of harp, tambour, violin, flute, dulcimer and lyre instruments. Farobi was intimately acquainted with the musical culture of various peoples living in the Middle East due to his sharp taste and remarkable musical ability. The musical heritage of the peoples of Central Asia and Iran, in particular, had a great influence on the formation of his musical views. It is known in the works of Farobi that these peoples deeply mastered the scientific and practical aspects of their musical heritage.

According to our teacher Zokirjon Aripov in his book "Oriental Sources", Mahmud Hafni did a good job as one of the organizers of the study of musical treatises in Arabic written in the Middle Ages. He was active in the publication of critical texts of Farobi's "Great Music Book" and wrote introductions to them. Mahmoud Hafni, in collaboration with the German orientalist E. Neubauer, translated and published the music section of Farobi's Book of Iqqa and Ibn Sina's Book of Healing on music. Among E. Neubauer's scientific works on medieval musical treatises, Farobi's work on the theory of iyqa is highly valued $\{4\}$. $\{4.5\}$., In one of the legends, there are myths that Farobi sang tune, confused people, sometimes made the enthusiastic people sad, and sometimes put the smart ones to sleep and amazed the fans. In science, he left an indelible mark on the history of musicology, creating works of universal significance.

Farobi wrote many works on music. The sources include his "Classification of Sciences" ("Ihsa al-Ulum"), "The Great Book of Music" ("Kitab al-musiqa al-kabir"), "Introduction to Music" ("Mad-hal fi-l-music"), " The Book of the Classification of Rhythms "(" Kitab ixsa aliko ") and many other works are mentioned. Some of these works are kept as manuscripts 
in various libraries around the world. Two works of music by Farobi have been widely introduced into modern science. These are the music section of the Classification of Sciences and the Big Music Book.

Farobi gives a broad and perfect account of each of the above-mentioned categories of science and authorship. Science begins with the study of the musical and physical properties of sound. Sound is defined as a physical phenomenon that results from the vibration of any hard or soft body. The acoustic properties of sound, that is, the relationship between the volume of a vibrating body and the pitch of sound, are explained in the example of various musical instruments, and the factors for expressing their quantities in a mathematical style are explained. "Melodies are compared to a poem. In poetry, the primary element is the letters, the cause of which is the formation of verses and bytes from their combination of vatad, and in the structure of melodies there are primary and secondary elements from which the melody are compared. The only thing that plays the role of letters in poetry is melodies, "Farobi wrote.

So, the concept that comes from the sound is melody (musical sound, tone, lad). Farobi discusses the causes of low-pitched melodies, the factors of proportionality, and the effects of emotion through these characteristics (Farobi. The Great Book of Music, Cairo, published in 1967). The category of interval is one of the central concepts of science. Because the lad itself cannot yet be a separate piece of melody.

It is impossible not to look at the work of our creative master Borbad, who left his mark on the performing arts with his immortal masterpieces. The great thinker Babad was born in Merv in 585, the first professional musicologist, composer, singer, poet and performer in the East. The future composer was educated in madrassas in Arab and nonArab countries. The composer's works such as "Navruz buzruk", "Gulzor", "Sabz bahor", "Rohi gul", "Polizbop" directly reflect the beauty of nature. He wrote melodies and songs dedicated to the seven days of the week, the collection "Khusrav Ohanglari", the thirty days of the month, and the thirty days of the year. Many of the melodies and songs composed by the great composer Borbad have survived to the present day and have been sung by the people and copied from book to book.

Abu Ali ibn Sina, Safiuddin Urmavi, Khoja Abdulkadir Maroghi, Abdurahman Jami, Najmiddin Kavkabi, Darvesh Ali Changi, as well as the great thinkers and scholars mentioned above, wrote not only scientific collections, but also textbooks and it is difficult to reach the end of the scientific works they have left, because the untranslated cases of the works written by our thinkers are still present today. It is safe to say that the performance skills of our aforementioned scholars have assessed the difficulty levels of musicology.

The contributions of the above-mentioned scholars and thinkers to the performing arts are at the heart of our immortal musical masterpieces. As long as there are such expressions as white and black, low and high, night and day, good and bad, negative and positive, there will be an opportunity to differentiate and choose the best.

Even before the independence of independent Uzbekistan, we know from historical sources that our scientists did not stop creating in the science of music. The works are in line with the way of life of the people, and the works that are specific and appropriate to the requirements of the time 
are still in the hearts of listeners, without losing their place in the hearts of listeners. As we turn the pages of history, we are reminded of the words of the first President IA Karimov: "The future of a nation with high spirituality is great."

According to Zahiriddin Muhammad Bobur (1483-1530) in the educational-methodical collection "History of the Art" by R.A. Toshmatova, Alisher Navoi in his time helped many players of harp, flute, violin and dulcimer to show their talents, in "Boburnoma" we can see the information about the names of performers of Uzbek folk instruments. According to Babur, "Skilled musicians such as Master Muhammad Shaybani and Husayn Uddi gained great fame and great success under the direct help and patronage of Bek (Navoi)" $\{5\}$. $\{5.82\}$. Babur also mentions such skilled performers as Shah Qulli-Gijjaki, Husayn Uddi, Khoja Abdullah Marwarid Qanuni. During the Navoi period, the performance of flute, harp, violin, kanun, bugle, zurna, drums, doyra, and dulcimer was widespread. They are all used in both ensemble and solo $\{5\} .\{5.83\}$

Today, the founder of Uzbek art, playwright, composer, teacher, public figure H.H.Niyazi, who contributed to the development and performance of the performing arts (18891929), is one of our scientists who made a significant contribution to the development of music. His name is associated with the creation of his first songs in modern interpretations, such as "We are workers", "Long live Soviet", "Workers", "Workers, awake!", "Worker grandfather", which are among the works that move the human heart. Hamza's multifaceted creative and pedagogical activity confirms that he played an important role in the formation and development of the Uzbek school of performing instruments.
Mulla Tuychi Tashmuhammedov, Ilhomjon (dutar player), Karimbek khoja (violin player), Shoborot (tambour player), Ilyoskhoja (dulcimer player) and apprentices Yunus Rajabiy and Risqi Rajabiylar, Imomjon Ikramov, (violin composer), Po'jochchi composer), Abdusoat Vahobov (dutar player), Hafizs Shoqosim, Shoolim, Shoakbar Shojalilov served as a valuable force in introducing the performing arts to the public.

It is no secret that the scientific works of composers and creators have been studied over the years, but the process of their study is slow. What is the reason for this? The question naturally arises. Time or if we look for an excuse for the age of technology, there are a lot of them, and it is no exaggeration to say that the word "speed" is not one of the most pressing issues of our time. It would not be a mistake to say that science is not about speed, but about understanding it and absorbing it in the heart. It is true that these words are deeply ingrained in the human heart, but it is shocking that today most of our young people have light-hearted world music instead of the historical processes that they should know in their lives.

In his book "The Priority of Law and Ensuring Human Interests - a Guarantee of the Country's Development and Welfare", President Mirziyoyev noted the following speech of the First President at the historic session of the Supreme Soviet on December 8, 1992. "For the last seventy years, we have lived in a state of dependence and worship. We have always considered the state to be the owner of the country, of all its riches and property. This is a fundamental turning point in the Constitution. That is, our Constitution includes an article that states that "the state, its agencies and officials are accountable to society and citizens." 
Man, his life, liberty, dignity and other inalienable rights and freedoms are now considered sacred and guaranteed by the state. " $\{6\} .\{6.5\}$

It is safe to say that the comprehensive reforms carried out by our President are bearing fruit today. However, in response to executive discipline, we can all achieve our goals quickly and effectively only if we perform the tasks we are told from the heart.

The reforms carried out by the first President I.A. Karimov for the development of the country will serve as a great basis for achieving high goals, in short, it is no exaggeration to say that in a short period of time we have passed the transition period. Along with the reforms carried out by President Sh.M.Mirziyoev in every sphere, attention to art is becoming one of the highest. The purpose of the Resolution of the President of the Republic of Uzbekistan dated May 31, 2017 on measures for further development of culture and art was as follows: to increase the role and importance of culture and art in our life at a new stage of renewal and modernization of our country. and we have witnessed that it encompasses higher goals, such as nurturing in the spirit of devotion. This decision has had a profound effect on all areas of the arts. On August 3, 2017 at the meeting of the President with the intelligentsia of the country on the topic "Development of literature and art, culture - a solid foundation for raising the spiritual world of our people" objectively and critically assessed the development of culture and art , in-depth analysis of the current problems and their solutions, the activities of creative associations, the Ministry of Culture and its affiliates and organizations, emphasizing the role of creative intellectuals in society today, the role and function of the reform process.
We can see in the achievements that this decision is being passed step by step. Now let's just look at our successes and finally analyze our shortcomings and problems as well. It is no exaggeration to say that these draft resolutions have also had an impact on the performing arts, and a lot of work has been done and is being done to pay attention to our forgotten status art, to give importance to composition. Why does this process suffer from successes and failures in the performing arts? The question naturally arises. It is difficult to explain my solution without a deeper analytical approach to this question. As we all know, it takes a lot of hard work and effort to perform a sozda. It is not in vain that we say that $1 \%$ talent is $99 \%$ labor. Analyzing these words, it is necessary to know how to hold the word, to know the location of the sounds in it, to know the position of the instrument in low and high register, and only then to work on the work. No matter how complex the process, now that the performer who has set up the process is not practicing that instrument every day, the skill he is working on will stop somewhere instead of growing. This is just the beginning of what we are talking about. At a time when the abovementioned master thinkers and scientists are musicians, composers, singers and musicologists at the same time, is it enough a single practice for the younger generation to reach the same level? Not, of course. There is a beautiful saying in our nation, "A student who has not seen a teacher walks to every position," and indeed, a student who has followed the path shown by a teacher has never been inferior. It is not for nothing that we say that the student has passed from the teacher $\{5\} .\{5.72\}$

It is true that President Sh.M.Mirziyoev said the following on the basis of building a free and prosperous, democratic state of 
Uzbekistan. It is the people who brought us up. Who should we consult with - first of all with our people. Then our people will agree with us. If the people agree, our work will be fruitful and blessed. If the people are pleased with us, the Creator will be pleased with us.

In this sense, there is a deep life wisdom and philosophy in the lines of the great Alisher Navoi, "If you are a man, don't say a man, who doesn't care of the grief of the people." In other words, living in this world thinking of people's worries is the highest criterion of humanity, and our great ancestor states that a person who is far from the sorrows of the people cannot be included in the human race $\{7\} .\{7 \cdot 17-18\}$

In the educational-methodical collection "History of Performing Arts" by A.R. Toshmatova the history of the formation of the ways of performance is well covered, and we can see that the scientific books of our thinkers are also mentioned. The theoretical views of Eastern scholars were formed on the basis of existing experience in the performing arts, and in their treatises they provided detailed information about the role and importance of music in society. Al-Farabi's (873-950) "Great Book of Music" ("Kitab almusiqa al-kabir"), Ibn Sina's (980-1037) "Book of Healing" ("Kitab ush-shifo") encyclopedia, "A treatise on music", Al -In Khorezmi's (X) century "The key to knowledge", Safiuddin Urmavi's (1216-1294) book "On nobility" or "Sharafiya" book, A.Jami's (1414-1492) book "Book about music" about music performance and folk instruments data are described $\{5.79\}$.

If we make the most of every minute we spend, we will surely achieve our goal. What tasks can our spirit perform and help us? We can answer this question as follows. One of the main points is that many of our scientists have commented on the human spirit in their works. No matter how beautiful and alert our spirit is, it will help us to overcome and fulfill all the tasks before us with a strong will.

If an educator wants to bring up a person in all respects, that is, in order to bring up a perfect person, he must study him in all respects. Of course, it is impossible to know the mental characteristics of students without in-depth study of the theoretical problems of psychology, without acquiring the skills and abilities to conduct practical exercises in this subject, at least simple and easy to perform.

If social development for our old and eternally young country is perceived and analyzed from a psychological point of view, then our people used ethnopsychological knowledge in the process of education and upbringing, psychologically influenced fighters in military campaigns, instilled in them a sense of confidence, the practical application of verbal and nonverbal forms of behavior, grom the creative products of such great medieval scientists as Farobi, Beruni, Khorezmi to the 30 s of the XX century, scientific research was carried out and it is possible to see a fact that does not require proof.

Psychology has been taught as a subject in higher education in Uzbekistan since 1928. (There is no doubt that L.S. Vygotsky's public lectures in Uzbekistan at the same time in Central Asia was a key factor in accelerating this process.)

In the textbook of music psychology, G. Kadyrov justified the extent to which psychology can have an impact on the performing arts, as well as on the same process.

As early as the Middle Ages, the great thinkers of the East studied music psychology, the 
influence of music on the heart, mood and the human body: Farobi's "Great Book of Music" and other works, Ibn Sina's "Book of Healing", "Book of Salvation", "Encyclopedia" sections on music, such as Abdurahman Jami's Risolai musiqa $\{8\}$. $\{8.4\}$ can be examples for them. "Psychology" (Greek) - "psycho", "psyuxe" (spirit, soul); "Logia" means "logos" (doctrine, science). G. Kadyrov described the views of our scientists in the psychology of music as follows.

According to the Greek philosopher Plato (fifth century BC), the power of a state depends on what kind of music, in what tone, and in what rhythm it is played. Plato and his followers believed that the state needed music to help lift a person to great heights.

Aristotle (fourth century BC) also considered music as a means of harmonizing the individual with social life. Aristotle developed the doctrine of mimesis, which revealed the inner world of man and ways to influence him through art. In the theory of mimesis, the concept of 'catharsis' was developed. According to him, ancient Greek tragedies cleared the viewer's mind of the pains of illness. In the process of deep experiences, man is spiritually purified, his heart rises from its individuality, its uniqueness to its generality.

Aristotle described in detail the musical modes that change the psyche. Music in one mood makes one feel compassionate and gentle, while in another it can cause nervousness or excitement. Thus, the music in the Dari, Phrygian, and Lydian lads had a positive effect on one's spirit and health, while the music recorded in other lads was recommended not to reach the ears of the younger generation. Similar recommendations have been developed for musical instruments.
The ancient Greeks called an illiterate person 'axareutos', which meant a person who was unfit to sing, dance, play an instrument, and therefore participate in a 'choir'. The musicalchoreographic movement that united the population of the ancient Greek city was called "chorea". Therefore, we need to pay attention to all aspects of music performance and take a scientific approach.

The phrases mentioned by our scholars can confirm that the scholars of world music culture have also brought up teachings that are almost semantically close to each other in the process of education. Even in church music, the priests, in their edicts, stipulated that schoolteachers should consider the art of church singing as a subject to be compulsorily taught: "You shall establish" schools 'in your homes. "So that our children may learn to read and write as well as sing, and in the future to teach their children that this is God's will ..." $\{9\} .\{9.76\}$

As mentioned above, where there is success, there are also shortcomings. What exactly do we mean by deficiency? Of course, it is a pity that today the culture of listening to our young people, as well as the culture of performance, is neglected. What is the reason for this? Let's take a look back and compare today and yesterday at a time when all the conditions are being created by our President.

The high level of attention and recognition given to music and art schools can be seen in the ongoing reforms, which are one of the highest goals to bring them to the world stage. Let's take a look at the life of developed countries together. The great composers of the world, such as Mozar, Bach, Beethoven, Shopen, List, Tchaikovsky, have taken their place in the books of the world, as well as in the hearts of listeners. Of course, this is due to the teacher's teachings and the 
first lessons he learned from his youth in music schools. As we study the work of each performer and artist, we can learn from the books left by our scholars that his father or mother felt his interest in music and took him into the hands of a teacher, helping him to study at a music school. Unless conditions are created for family education, both aspiration and love for creativity will slowly fade away.

But at the same time, it is unfortunate that some of our listeners do not have the patience not only to listen to our world classical music, but also to play our own national music. We are glad to see our young performer going to music and art schools, because he is learning to spend his free time productively. Feeling the complexity of playing the instrument, he continues to work, showing his interest and love for the word in his performance skills. It is no exaggeration to say that this is the result of the efforts of parents who think about the future of their children.

As a proof of the above-mentioned words, President Sh. Mirziyoyev said that a number of draft resolutions have been adopted and their implementation is bearing fruit, but if we are more interested in the implementation of these resolutions in remote areas, we will show our attention and love for our young executive. . It is inevitable that we will lay the groundwork for a brighter future only if we contribute to the rapid development of these processes, imagining how many young performers from our remote areas will come to participate in the city competitions.

But sometimes it would be a mistake to say that our negligence is causing them to fade their creative labors a little tomorrow. If we look at these cases until 2017, we can see that in 2017, in accordance with the decree of the President on measures to further develop and improve the field of culture and arts, associations of composers and composers of Uzbekistan began to operate in the regions. The purpose of this association was to find creative composers and composers from the regions and to encourage them by recognizing their creative work. Creative composers and musicologists, who started with 3 people in each region, traveled to music and art schools, houses of culture, secondary schools in remote areas to organize open dialogue and master classes and creative meetings, as well as discover aspiring composers and composers. are sharing. Rustam Abdullayev, the head of the association, said in an interview with the members of the association: "The creator does not need much, he needs a listener who respects his work, and inspires him to create new works." In fact, it is no exaggeration to say that you and we are the ones who guide these artists in the right direction, appreciate their work and serve as a valuable force in transmitting it to future generations.

\section{CONCLUSION}

In short, it is safe to say that the performing arts are on the rise and serve as a platform for the youth of tomorrow, so it is inevitable that we will achieve our goal as we strive with all our heart to achieve creative perfection in scientific research.

\section{REFERENCES}

1. Musical aesthetics of the countries of the East. M., 1967, p. 271-272.

2. Navoiy A. Mahbub ul-qulub. T., 1970, 29-p.

3. Karimov I.A. We build our future with our own hands. Volume 7 "Uzbekistan", T., 1999, 300-p.

4. Zokirjon Oripov. Oriental musical sources (X-XI centuries) T., - 2008. 5-b.

5. R.A. Toshmatova "History of Performing Arts” T., 2011. 82-b. 
6. R.A. Toshmatova "History of Performing Arts" T., 2011. 83-b.

7. Sh.M.Mirziyoev Ensuring the rule of law and human interests - the key to the development of the country and the wellbeing of the people T., Uzbekistan 2017.

8. R.A. Toshmatova "History of Performing Arts" T., 2011. 72-b.

9. Sh.M.Mirziyoev Together we will build a free and prosperous, democratic state of Uzbekistan. T .: “O'zbekiston”, 2017. 1718-b.

10. Music Psychology (lecture course): Textbook / Compiled by RG Kadyrov. - T .: Music, 2005.4.

11. Yu.M.Nosirova. History of Russian music (IX-XVIII centuries) Textbook for students of musical higher education institutions T., 2009y. 76-b.

12. Ahmedov $M$. Ahmedova-Olimboeva K. "Uzbek folk musicians" I book., G.Gulam. $1959 \mathrm{y}$.

13. Jabborov A. Composers and musicologists of Uzbekistan. T., $2004 \mathrm{y}$.

14. Composers of Uzbekistan G. Gulom. 1978 $y$.

15. Avedova M. Art of design of musical instruments T.,

16. Tashmatova A. Catalog of the Museum of Musical Instruments. T., $2006 \mathrm{y}$.

17. Tashmatova A. Catalog of the Museum of Musical Instruments T., 2006

18. Nasiba Turgunova "Life in Art" Namangan Publishing House, 2007.

19. Lutfullaev A. History of performing arts on Uzbek folk instruments. T., $2006 \mathrm{y}$.

20. P. Zokirov "Composer and composition" Jizzakh 2009.

21. Do'simbetov B. Created by Mirza Toirov

22. Abstract Manuscript. T.,

23. Xodjaeva S. Principles of education of the teacher A.Malikov. T., 2009 y. Manuscript abstract.
24. Abdurakhimova F. Anvar Liviev. Sketches for a creative portrait. T., 2004 